\title{
LIN28B wt Allele
}

National Cancer Institute

\section{Source}

National Cancer Institute. LIN28B wt Allele. NCI Thesaurus. Code C101417.

Human LIN28B wild-type allele is located in the vicinity of $6 \mathrm{q} 21$ and is approximately 126

$\mathrm{kb}$ in length. This allele, which encodes protein lin-28 homolog $\mathrm{B}$, is involved in the regulation of pre-miRNA degradation. 